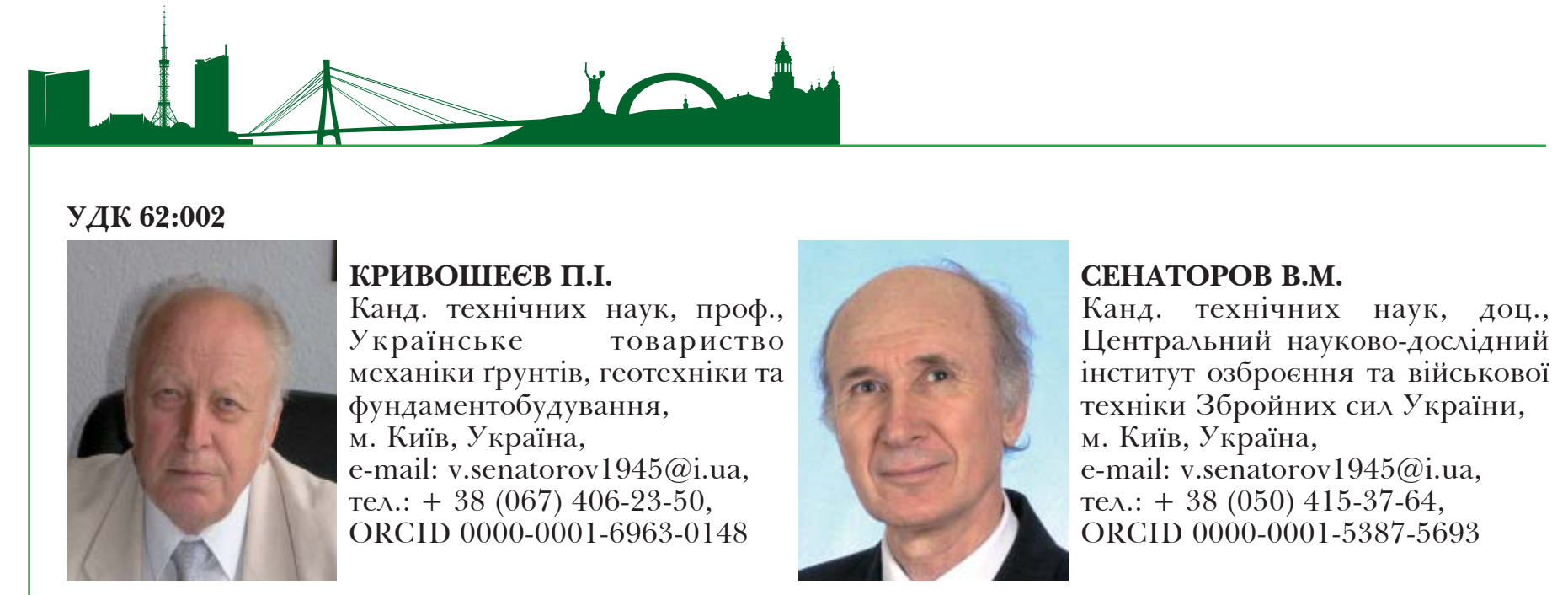

\title{
СЕЙСМОСТІЙКЕ БУДІВНИЦТВО У ВИДАННЯХ МІЖНАРОДНОЇ ФЕДЕРАЦІЇ ЗААІЗОБЕТОНУ
}

\section{АНОТАЦІЯ}

Основним виданням Міжнародної федерації залізобетону (fib) є Бюлетень. За станом на сьогодення видано понад 90 бюлетенів, серед яких 7 присвячені проблемам сейсмостійкого будівництва. Зокрема:

Бюлетень № 24 «Сейсмічна оцінка доцільності відновлення залізобетонних споруд». Дано огляд основних та інноваційних методів для попередньої або детальної оцінки окремо існуючих будівель щодо доцільності відновлення. Описано стратегії та інструкції щодо вибору тої чи іншої технології відновлення.

Бюлетень № 25 «Сейсмічне проектування залізобетонних будівель 3 урахуванням зсуву». Підсумовано, критично проаналізовано і співставлено всі відомі підходи до проектування залізобетонних споруд, що базуються на теорії зміщення, що у подальшому сприятиме покращенню проектних норм i практичному використанню найбільш раціональних, надійних проектних методів.

Бюлетень № 27 «Сейсмічне проектування збірних залізобетонних будівельних конструкцій». Представлено широкий систематизований огляд основних особливих шляхів об'єднання збірних елементів для створення ферм, стін, подвійних систем і діафрагм, що протидіють згинальному моменту, в той же час описуючи концепції і даючи детальні пояснення особливостей дії механізмів опору поперечному навантаженню. Обгрунтовані й описані унікальні інноваційні рішення, зокрема, так звані «гібридні системи», в яких використовуються розв'язані напружені елементи в сполученні 3 низьковуглецевою сталлю для з'єднання елементів таким чином, аби мінімізувати залишкову деформацію.

Бюлетень № 35 «Відновлення бетонних конструкцій за допомогою зовнішнього обв'язування фіброполімерами з огляду на можливе застосування в сейсмічних регіонах». Розкрито зміст сучасного методу відновлення за допомогою фіброполімерів і надано відповідні положення з трьох наведених нижче нормативних документів: EN 19983:2005 «Еврокод 8: Розрахунок конструкцій на сейсмостійкість - Частина 3: Аналіз і відновлення будинків»; Проекту нормативу Туреччини щодо сейсмічного проектування за 2005 рік; Італійської настанови CNR-DT 200/04: «Інструкція щодо проектування, виконання i контролю за характеристиками конструкції при їі зміцненні за допомогою фібро-полімерних композитів».

Бюлетень № 39 «Сейсмостійке проектування i відновлення моста - конструктивні рішення». Цей бюлетень є підсумком сучасного рівня знань про мости, що підпадають під дію сейсмічних впливів. Це корисне джерело інформації для інженерів, які залучені до нетривіальних завдань сейсмостійкого проектування мостів.

Бюлетень № 68 «Сейсмостійке проектування на основі імовірнісного підходу». Бюлетень носить оглядовий характер щодо відомих методів проектування сейсмостійких споруд.

Бюлетень № 69 «Критичне порівняння основних сейсмічних норм для будівництва». У бюлетені дано порівняння норм СШІА, Японії, Нової Зеландії, Европи, Канади, Чилі та Мексики.

КлючОВ СлОВА: Міжнародна федерація залізобетону, бюлетень, сейсмічне проектування

SEISMIC CONSTRUCTION IN THE PUBLICATIONS OF THE INTERNATIONAL FEDERATION FOR STRUCTURAL CONCRETE

KRYVOSHEIEV P.I. PhD, Prof., Ukrainian Society for Soil Mechanics, Geotechnics and Foundation Engineering,

Kyiv, Ukraine,

e-mail: v.senatorov1945@i.ua,

tel.: + 38 (067) 406-23-50, 
ORCID 0000-0001-6963-0148

SENATOROV V.M. PhD, Ass. Prof., Ukrainian Armed Forces Central Research Institute of Weapons and Military Equipment,

Kyiv, Ukraine,

e-mail: v.senatorov1945@i.ua,

tel.: + 38 (050) 415-37-64,

ORCID 0000-0001-5387-5693

\section{ABSTRACT}

Bulletin is a basic issue of the International Federation for Structural Concrete (fib). 90 Bulletins approximately are issued beginning from 2002, 7 from them are devoted to seismic construction problems. Authors are acquitting the Ukrainian specialists with content of these fundamental works.

Bulletin № 24 «Seismic assessment and retrofit of reinforced concrete buildings». Review of basic and innovation methods for preliminary or detailed assessment for separately existing structures is given there with viewpoint of retrofitting. Strategies and instructions for choice of relevant technology are described in Bulletin.

Bulletin № 25 «Displacement-based seismic design of reinforced concrete buildings». All wellknown approaches to RC structures design on base of displacement theory are critically analyzed and compared there. In future it will promote to imperfection of design codes and practical use of the most rational and durable design methods.

Bulletin № 27 «Seismic design of precast concrete building structures». Comprehensible and systematized review of the basic ways to join of the precast elements for girders, walls and diaphragms resisting bending moment is presented in Bulletin. Also the conceptions and detailed explanations for peculiarities of resistance action to transverse load are presented there. There The unique innovation solutions, particularly, "hybrid systems", where the decoupled stressed elements in conjunction with extra-soft steel are applied to join the elements for minimization of the residual deformation, are grounded and described.

Bulletin № 35 «Retrofitting of concrete structures by externally bounded FRPs with emphasis on seismic applications». Essence of a modern method dealing with retrofitting with the fibro-polymers application is described in Bulletin. Besides that, there are the relevant provisions of the listed below documents: EN 1998-3:2005 «Eurocode 8: Design of structures for earthquake resistance - Part 3: Assessment retrofitting of buildings»; draft of Turkish seismic design code, 2005; Italian regulatory document CNR-DT 200/04, «Instructions for design, execution and control of strengthening interventions by mans of fibre-reinforced composites».

Bulletin № 39 «Seismic bridge design and retrofit structural solutions». This Bulletin is a result of modern acknowledgment level about bridges under action of seismic actions. It is useful information source for engineers involved in seismic designing of the bridges.

Bulletin № 68 «Probabilistic performance-based seismic design». Bulletin has a distinct educational character and it provides a clear overview of the available design methods.

Bulletin № 69 «Critical comparison of major seismic codes for buildings». Comparison of USA's, Japan's, New Zealand's, Europe's, Canada's, Chile's and Mexico's codes is presented in Bulletin.

KEY WORDS: International federation of structural concrete, bulletin, seismic design

\section{ВСТУП}

У 1998 році в результаті об'єднання Европейської комісії з проблем бетону (СЕВ) і Міжнародної федерації попередньо напруженого бетону (FIP) було створено нове громадське об'єднання - Міжнародну федерацію залізобетону (fib). Основна мета fib розвиток на інтернаціональному рівні теоретичних i практичних досліджень, пов'язаних із технічними, економічними та естетичними аспектами бетону i його впливом на оточуюче середовище [1].

Сьогодні fib об'єднує у своїх рядах національні групи 45 розвинутих країн $з$ усього світу і понад 1000 індивідуальних членів [2].

Свою діяльність fib здійснюе за допомогою технічних комісій. Серед них чільне місце займає комісія 7 «Сейсмостійке проектування» в складі трьох дослідницьких груп: група 7.5 - «Сейсмостійке проектування будівель 3 використанням високоефективних матеріалів»; група 7.6 «Критичне порівняння основних сейсмічних норм для проектування будівель»; група 7.7 «Сейсмостійке проектування будівель на основі імовірнісного підходу».

Область наукових інтересів комісії охоплює такі проблеми [2]:

- розробка нових концепцій і правил для сейсмостійкого проектування нових залізобетонних споруд та підвищення сейсмічної безпеки існуючих конструкцій;

гармонізація і удосконалення нормативних документів щодо сейсмостійкого проектування.

Основним виданням fib $є$ Бюлетень. Станом на вересень 2018 р. видано понад 80 бюлетенів, серед яких шість стосуються проблем сейсмостійкого будівництва: №№ 24, 25, 27, 35, 39 і 69. Проблеми 3 мовним бар'єром стають перепоною для українських фахівців щодо ознайомлення із змістом цих бюлетенів. Примірники бюлетенів отримує лише ДП НДІБК, що представляє українську групу fib згідно рішення Держбуду України від 04.11.1998 р. № 59 «Про забезпечення участі у роботі міжнародних організацій з бетону та залізобетону».

META ЦІСЇ CTATTI - дати можливість фахівцям України ознайомитись із змістом цих шести бюлетенів і розглянути шляхи приєднання інших організацій до української групи fib. 


\section{man}

\section{ЗMICT БЮЛЕТЕНIB}

Нижче надано стислу інформацію щодо змісту бюлетенів.

Бюлетень № 24 «Сейсмічна очінка дочільності відновлення залізобетонних споруд» (2003 p., 312 с.). Бюлетень містить наступну інбормацію.

Глава 1: Цілі розгляду і системний аналіз. Ця глава обгрунтовує якісний підхід під час аналізу доцільності відновлення споруди, роблячи акцент на поняттях і судженнях інженера-проектувальника. У цій главі описано:

- основні концепції сейсмічного опору і реакції;

- загальні причини/джерела вразливості існуючих будівель (з багатьма ілюстраціями руйнувань в якості прикладів);

- відомі варіанти відновлення та їх раціональність: «за» і «проти»;

- сучасну філософію цілей діяльності під час оцінки або відновлення існуючих будівель;

- соціально-економічні проблеми, що важливі для відновлення (вартість, відповідальність, вплив на середовище мешкання і оточуюче середовище, збереження пам'яток історії i таке інше).

Глава 2: Огляд методів сейсмічного оцінювання. В цій главі наведено широкий огляд основних та інноваційних методів для попередньої або детальної оцінки окремо існуючих будівель (базується на знанні діючих сил або зміщень). Усі методи описано незалежно від національних/регіональних норм або стандартів (тобто в більш загальних термінах). Методи детальної оцінки, що описані тут, призначені для застосування (і мають застосовуватись) під час оцінки доцільності відновлення споруди та ранжируванні результатів відновлення.

Глава 3: Поводження не сейсмічно спроектованих будівельних елементів під час циклічного впливу. Описано поводження залізобетонних елементів з'єднань під час циклічного навантаження, акцентуючи увагу на впливі недоліків проектування на протидію сейсміці. Поводження описується 3 декількома альтернативними моделями i 3 порівнянням 3 результатами експериментів (вивчення баз даних, увагу привернуто до розбіжності даних).

Глава 4: Технології сейсмічного відновлення. В цій главі зроблена спроба всебічного розгляду існуючих технологій відновлення, включаючи:

- технології, що використовуються;

- експериментальні дані щодо відновлених конструкцій;

- інженерні моделі для розробки проекту відновлення;

- рекомендації для концептуальног детального проектування.

У главі також описані стратегії та інструкції щодо вибору тієї чи іншої технології відновлення. На рис. 1 приведені приклади підсилення конструкцій для протидії зрізу.
Глава 5: Імовірнісні концепції і методи. У главі описано моделювання випадкових впливів: рух, обумовлений сейсмікою, міцність або деформація. Також розглянуті два простих, але ефективних імовірнісних метода оцінки, що базуються на моделюванні реакції при нелінійному динамічному аналізі: метод 2000 SAC/FEMA 350 (стосовно до реального чотирьохповерхового просторового залізобетонного будинку) і метод «Ефективного аналізу ламкості» (стосовно до трьохповерхового залізобетонного каркасу).

Глава 6: Приклади. Два реальних будинки в Туреччині оцінені перед і після відновлення, 3 використанням методу Федеральної агенції управління надзвичайними ситуаціями (FEMA 273/356), процедури 3 лінійним динамічним, нелінійним статичним «вирівнюванням», а також комбінованого спектрального методу Ради прикладних технологій США (АТС-40) і нелінійного часового аналізу для верифікації вирівнювання. Далі два каркаси типового старого італійського проекту були детально проаналізовані різними методами - від лінійного динамічного до нелінійного часового аналізу 3 оцінкою «вирівнювання» (методи FEMA 273/356, АТС-40 і N2 - нелінійний метод для аналізу сейсмічного пошкодження залізобетонних споруд). На завершення, оцінювався чотирьохповерховий здвоєний будинок, типовий для грецького будівництва, з використанням FEMA 273/356 лінійної і нелінійної статичних процедур та новозеландського підходу на основі теорії зміщення.

Бюлетень № 25 «ейсмічне проектування залізобетонних будівель з урахуванням зсуву» (2003 p., 197 c.).

Головна мета бюлетеня - підсумувати, критично проаналізувати і зіставити всі відомі підходи до проектування залізобетонних споруд, що базуються на теорії зміщення, щоб в подальшому це сприяло покращенню норм проектування i практичному використанню найбільш раціональних, надійних проектних методів.

У главі 1 розглянуті поняття «рівні поводження»,
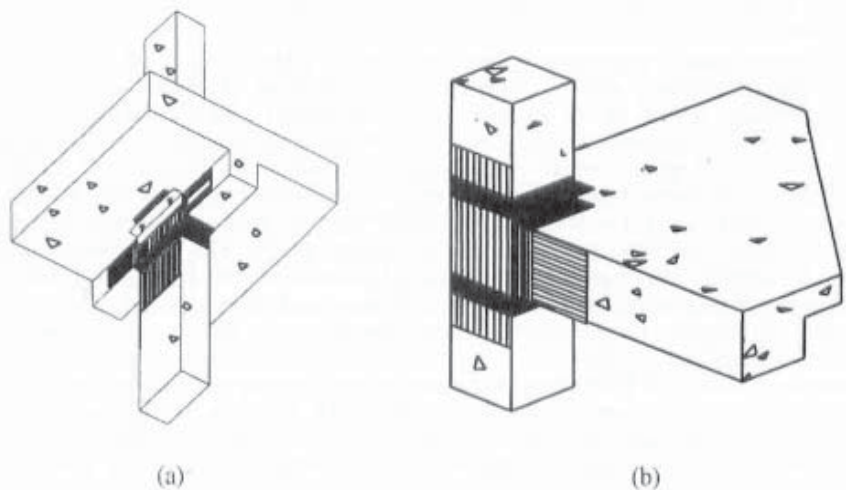

Рис. 1. Зовнішне а) і внутрішне б) підсилення з'єднання балки з колоною за допомогою листової фібри 
«сейсмічна небезпека» і встановлено їх взаємозв'язок, що дозволяє сформулювати задачі діяльності. Пропонується використовувати шість рівнів поводження: початок небезпеки (damage onset); робочий рівень (operational level); безперервне перебування (continued occupancy); здатність до ремонту (repairable level); безпечний для перебування (life safe) і колапс (collapse). Тобто, поняття «рівень поводження» в цьому бюлетені можна розглядати як граничний стан конструкції.

Це пов'язане 3 тим, що під час проектування, що базується на знанні технічних характеристик, проектант повинен чітко встановити рівні поводження i сейсмічні навантаження, щоб визначити можливі зміщення. В цій главі дано критичний огляд граничних станів конструкції при різних видах діяльності.

У главі 2 дано огляд фундаментальних принципів, що пов'язані з рухом грунту під час землетрусу, i наслідків, що пов'язані зі зміщенням споруди. Дано систематизований огляд загальних лінійних i нелінійних принципів структурної динаміки, загальних підходів до оцінки зміщення грунту i конструкції i, наприкінці, - загального розуміння заходів, що необхідні для контролю і оцінки припустимості зміщень споруди в різних перетинах.

Глава 3 є основною в бюлетені - тут дано критичний підсумок проектних підходів, основаних на теорії зміщення, що були запропоновані різними дослідниками. В главі розкривається поняття «проектування на основі теорії зміщення», а саме: процедура розглядається як проектне рішення, опрацьоване під час аналізу деформації. Термін «деформація» краще, ніж термін «зміщення» в тому випадку, коли значення деформації оцінити легше, ніж значення зміщення.

Для адекватного зіставлення множини проектних підходів вводяться чотири критерії:

- роль зміщення в проектному процесі;

- вид аналізу, прийнятого в проектному процесі;

- обмеження на структурному рівні під час аналізу підходів;

- обмеження щодо застосування до визначеного граничного стану.

Загалом, розглянуто 19 проектних підходів, згрупованих в 7 різних категорій.

Проектування на основі теорії зміщення може вимагати спеціальної характеризації руху грунту. Це питання розглянуто в главі 4. До цієї глави включено відповідні поняття руху грунту для ненормованого формату аналізу, у той час як пікові параметри грунту, що необхідні для нормованих рівнянь зрізу основи, наведені тут, оскільки вони необхідні для визначення руху грунту під час аналізу.

Проаналізовано дві форми представлення руху: спектр землетрусу і записи рухів. Перша необхідна для типового спектрального аналізу i простоти адаптивного вирівнювання 3 масштабуванням спектру під час оцінки спектру потужності i проектування на основі теорії зміщення. Друга форма необхідна для інтегрованої оцінки часу реакції конструкції, де необхідні знання розподілу напружено-деформованого стану елементів конструкції в часі.

Глава 5 стосується фундаментальних проблем оцінки не пружного зміщення залізобетонних елементів і реальних оцінок їх ефективної міцності під час розтріскування, включаючи дію зрізу і косого розтріскування, прослизання анкеру, короблення арматури і циклічності навантаження.

База даних, що створена за результатами 1200 експериментальних досліджень, використана для розробки простих моделей для деформації залізобетонних елементів під час текучості та руйнуванні. Первинним критерієм деформації, що розглянуто тут, є відхилення (або поворот хорди) елемента відносно ділянки сколювання. Цей критерій охоплює макроскопічне поводження елементу в цілому, стосується більш глобальних характеристик сейсмічної реакції, таких як зміщення поверху, в той же час він є достатньою ознакою для руйнування на локальному рівні. Досліджуються два підходи: статистичний, тобто емпіричний, і більш фундаментальний підхід, оснований на принципах і механізмах поводження залізобетону.

У главі 6 наведені приклади застосування проектних процедур, описаних у главі 3, для ряду випадків. Тут же відмічаються і оговорюються труднощі, $з$ якими може зіткнутися проектант. Наведені результати п'яти прикладів використання восьми різних проектних підходів, що базуються на зміщенні з акцентом на таких моментах:

а) відносна легкість або труднощі, 3 якими проектний підхід може бути реалізований, i які очевидні обмеження можуть тут бути;

б) необхідна надійність, яка досягається для кожного підходу, і як вона співвідноситься 3 іншими підходами;

в) ефективність підходів, оцінена порівнянням податливості, що прогнозується, або відхилення для кожного прикладу з такими ж характеристиками, отриманими $з$ часового аналізу.

Приклади показують, що труднощі, з якими може зіткнутися проектант, різні для різних підходів. Окремі методи проектування прийнятні лише для деяких типів конструкцій, а інші привносять труднощі, що пов'язані з неправильними формами конструкцій та податливими основами. В більшості прикладів проектант повинен робити припущення, аби продовжити процес проектування, а в інших прикладах метод не спрощує проектування.

Після того, як розрахунок завершено, проводиться нелінійний часовий аналіз з використанням моделі міцності, що отримана для кожного розрахунку. Часові аналізи показують - усі проектні підходи забезпечують розрахунки, що гарантують не перевищення граничного стану. Не дивлячись 
на велику варіативність розрахункової міцності, різниця у відхиленні між підходами незначна.

Висновки глави 6 є важливими і дозволяють передбачити успішне використання проектних підходів на основі зміщення в практичній діяльності.

Бюлетень № 27 "Сейсмічне проектування збірних залізобетонних будівельних конструкцій» (2004 p., 263 c.)

3 глави 1 бюлетеня можна дізнатись про впровадження збірного будівництва в семи країнах 3 основних сейсмонебезпечних регіонів, про типи конструкцій, для яких передбачено збірність елементів, та про проектні критерії і положення, що діють в цих країнах. Дано посилання на відповідні документи і норми проектування.

Глава 2 містить огляд загальних сейсмічних проектних процедур для збірних залізобетонних конструкцій.

Наступні глави дають широкий систематизований огляд основних особливих шляхів об'єднання збірних елементів для створення ферм, стін, подвійних систем i діафрагм, що протидіють згинальному моменту, в той же час описуючи концепції і даючи детальні пояснення особливостей дії механізмів опору поперечному навантаженню. Тут не тільки обгрунтовані, але й описані мало розповсюджені інноваційні рішення, зокрема, так звані «гібридні системи», в яких використовуються розв'язані напружені елементи в сполученні 3 низьковуглецевою сталлю для з'єднання елементів таким чином, аби мінімізувати залишкову деформацію. Термін «гібрид» використано тут, щоб підкреслити середню характеристику реакції між нелінійно-пружною і пружно-пластичною, що зберігає властивості формуючої і змінної складової властивостей розсіювання деформаціями останньої.

Важливе місце займає глава 9, де показано, як 3 більш точних (і складних) моделей і методів аналізу можуть бути сформовані спрощені моделі стосовно до широкого класу альтернативних елементів з'єднання, виготовлених з низьковуглецевої сталі.

Інші, більш короткі, але не менш важливі, є глави, де описана концепція збірного будівництва (глава 3), гравітаційні системи протидії (глава 7), фундаменти (глава 8), різні елементи і конструкції (глава 10).

Бюлетень № 35 «Відновлення бетонних конструкиій за допомогою зовнішнъого обв'язування фбіброполімерами з огляду на можливе застосування в сейсмічних регіонах» (2006 p., 224 с.).

Бюлетень є першою публікацією матеріалів із скороченого курсу лекцій fib. Такі курси лекцій проводяться по усьому світу, охоплюють широкий спектр питань будівництва і останні знання вчених про будівельний бетон або окремі специфічні питання з даної теми. Курси були започатковані fib i проведені групою визнаних в усьому світі експертів iз залученням місцевих фахівців, які приймають активну участь у діяльності fib.
Бюлетень представляє матеріали, розроблені для скороченого курсу цих лекцій, що були прочитані у Туреччині в 2005 році. Курс базується як на досвіді експертів Туреччини, так і досвіді фахівців інших країн $з$ огляду на великий обсяг знань і матеріалів 3 цієї проблеми.

Бюлетень було використано як базу для іншого скороченого курсу лекцій fib щодо відновлення залізобетонних конструкцій за допомогою зовнішнього підсилення фіброполімерами, що був проведений у Мексиці в 2006 році.

У більшості країн світу житлові фонди застаріли i вимагають постійного експлуатаційного обслуговування і ремонту. Крім того, більшість існуючих конструкцій не відповідає сучасним вимогам i розрахунковим нормам. Проблема невідповідності конструкцій існуючих споруд особливо гостро стоїть в сейсмічних регіонах, навіть якщо сейсмічний розрахунок конструкції досить новий. Прямі і непрямі витрати 3 демонтажу i реконструкції споруд з конструктивними дефектами часто $є$ непомірно високими; більш того, це спричиняє значні витрати природних ресурсів та енергії. Тому відновлення конструкцій стає найбільш розповсюдженим методом рішення даної проблеми в усьому світі.

Методи зовнішнього підсилення конструкції фіброполімерами знову стають пріоритетними для відновлення конструкцій. Вони є більш зрозумілими і простими в застосуванні, ніж традиційні методи відновлення, знижують руйнування приміщень та підвищують їх експлуатаційні властивості, не ведуть за собою забруднення навколишнього середовища будівельним сміттям i відходами, зменшують небезпеку виникнення нещасних випадків і небезпеку для здоров'я на будівельному майданчику, а також сприяють зниженню рівня шуму і забруднення повітря прилеглої території.

Бюлетень розкриває зміст сучасного методу відновлення за допомогою фіброполімерів і подає відповідні положення 3 трьох наведених нижче нормативних документів: EN 1998-3:2005 «Еврокод 8: Розрахунок конструкцій на сейсмостійкість - Частина 3: Аналіз і відновлення будинків»; Проекту нормативу Туреччини щодо сейсмічного проектування за 2005 рік; настанови Італії CNR-DT 200/04 «Інструкція щодо проектування, виконання i контролю за характеристиками конструкції при іiі зміцненні за допомогою фіброполімерних композитів».

Бюлетень № 39 «Сейсмічне проектування $i$ відновлення моста - конструктивні рішення» (2007 p., 298 c.).

Цей бюлетень слід розглядати як підсумок сучасного рівня знання про мости, що підпадають під дію сейсмічних впливів. Це корисне джерело інформації для інженерів, які задіяні в нетривіальних задачах сейсмостійкого проектування мостів.

Чотири перші глави представляють, по суті, 
регіональне бачення вибору проекту, зіставлення i обговорення практики проектування в усьому світі, переваг і недоліків.

у главі 1 розглянуто переріз опори, обговорюється відповідна практика, необхідна для проектування колон 3 потрібною міцністю i пружністю. Представлено деталі армування опор, огляд регіонального вибору проекту: одна колона/ множина колон, суцільна/пустотіла колона.

У главі 2 описується з'єднання опори з надбудовою 3 акцентом на переваги та недоліки монолітного з'єднання у порівнянні з опорою на підшипниках. Дано опис регіонального вибору проекту для з'єднання і типу опори.

У главі 3 розглядається надбудова моста. Дається сейсмічний аналіз і регіональне бачення процесу вибору надбудови: форма перетину, жорсткість i вага, зміщення стиків та довжина основи при збірному і монолітному будівництві.

В главі 4 вирішується питання проектування фундаментів моста: розширений або пальовий фундамент і проектування фундаментів у водному середовищі. Описана типова регіональна практика проектування фундаментів.

Наступні три глави стосуються сучасних розробок 3 акцентом на підвищений контроль, на просторову варіативність руху грунту і накладання похибок розрахунків.

У главі 5 обговорюється стратегія контролю i представлено можливий варіант вибору опор, елементів ізоляції і розсіювання, розкачування фундаменту та ізоляція основи.

У главі 6 описані різні моделі для представлення просторової варіативності руху грунту з урахуванням втрати зчеплення, проходження хвилі і профілів грунту.

У главі 7 приведені наслідки пошкодження та зміщень грунту, стандартні ситуації, філософія та концепції проектування, вибір методу відновлення з прикладами накладання похибок розрахунків при проектуванні.

Останні три глави бюлетеня підсумовують проблеми існуючої практики зведення мостів.

У главі 8 даються підходи до ретельної перевірки для оцінки відновлення на основі методів, що базуються на фізичному моделюванні та інженерній практиці.

У главі 9 дано огляд оцінки існуючих мостів 3 врахуванням дефектів конструкції і граничних станів на основі моніторингу, а також на базі аналітичних методів і аналізу ламкості.

Остання 10 глава містить деталі проекту відновлення з прикладами виконання колон і опор, з'єднань колон і балок, фундаментів, надбудов, демпферів та ізоляторів при відбудові після сейсмічних подій.

Бюлетень № 69 «Критичне порівняння основних сейсмічних норм для будівництва»(2013 р., 216 с.).

У бюлетені дано порівняння норм США, Японії,
Нової Зеландії, Европи, Канади, Чилі та Мексики.

У першому розділі дано опис норм. У другому проведено порівняння найбільш проблемних трактувань. Воно містить сейсмічні проектні впливи та пов’язані з ними критерії, приклади проектування колон, балок, конфайнментів, стін та з'єднань.

Вважаємо, що цей бюлетень є корисним i унікальним інструментом для швидкого розуміння значущих особливостей основних світових норм щодо концептуальних підходів іправил застосування.

Всі бюлетені (мова - англійська) отримує за підпискою українська Національна група fib.

В бібліотеці ДП НДІБК накопичено понад 80 бюлетенів у друкованому вигляді, а бюлетені 31 по 47 номер зберігаються в електронному вигляді. Статутом fib передбачено, що копії друкованих i електронних бюлетенів мають право отримувати лише ті організації, що входять до Національної групи fib.

\section{ВИСНОВКИ}

Матеріали, що висвітлені у бюлетенях, становлять науковий і практичний інтерес для широкого загалу фахівців не тільки організацій будівельної галузі, залучених до будівництва відповідальних споруд, але й інших організацій міністерств, зацікавлених у створенні надійних, сейсмостійких будівель і споруд, в тому числі Міністерства надзвичайних ситуацій і Міністерства оборони.

\section{БІБІАІОГРАФІЧНИЙ СПИСОК}

1. The Intern. Federation for Structural Concrete. Електронний ресурс: www.fib-international. org. Дата звернення 25.07.2018 p.

2. Membership Directory 2017. Intern. Federation for Structural Concrete. - 2017. - 116 p.

\section{REFERENCES}

1. The Intern. Federation for Structural Concrete. Електронний ресурс: www.fib-international. org. Дата звернення 25.07.2018 p.

2. Membership Directory 2017. Intern. Federation for Structural Concrete. - 2017. - 116 p.

Стаття надійшла до редакції 10.07.2018 р. 